\title{
REKA BENTUK DAN HIASAN LINANGKIT PADA PAKAIAN TRADISIONAL DUSUN LOTUD DI TUARAN
}

\author{
Humin Jusilin \& Salbiah binti Kindoyop
}

\begin{abstract}
ABSTRAK
Sabah kaya dengan budayanya yang unik, termasuk fesyen pakaian yang amat rencam sifatnya. Pakaian tradisional etnik di Sabah mempunyai ciri-ciri yang amat menarik untuk diselidik kerana mencerminkan identiti budaya sesebuah etnik. Ia merupakan warisan peninggalan nenek moyang yang diturunkan sejak zaman berzaman. Dalam kajian ini, pakaian tradisional masyarakat Suang Lotud di daerah Tuaran, Sabah akan menjadi subjek kajian. Suang Lotud mempunyai tiga jenis pakaian tradisional iaitu pakaian yang digunakan oleh tantagas (ketua ritual), pakaian penari sumayau untuk tarian persembahan dan pakaian perkahwinan. Kajian ini tertumpu pada reka bentuk dan hiasan linangkit yang mendominasi hiasan gonob dan kuluwu dalam pakaian tradisional Lotud. Linangkit (sulaman) merupakan nama panggilan kepada motif geometri yang dihasilkan berasaskan teknik sulaman. Artikel ini ditulis melalui kaedah kerja lapangan dengan mengumpul dan mendokumentasi seberapa banyak rekaan linangkit tersebut dan mengkategorikan reka bentuk dan hiasan linangkit mengikut penghayatan estetika.
\end{abstract}

Kata Kunci: Pakaian tradisional, reka bentuk, linangkit, nilai estetika dan amalan adat.

\begin{abstract}
Sabah with its rich cultural background is reflected in the various cultural icons, in this case the traditional costumes. This article focuses in particular the cultural uniqueness of the linangkit design on the Lotud traditional costumes. The aspect which is of interest in this research is the reflection of the cultural identity of ethnic groups in their traditional costumes. Since traditional costumes are ancestral heritage handed down since time immemorial, the traditional costumes of the Suang Lotud in Tuaran, is the perfect choice of study. The Lotud(s) have three types of traditional clothes used by the tantagas or chair person in a traditional ritual. While the Sumayau dance costume is specifically for dance
\end{abstract}


performances, there are others used for weddings. This study is focused on the design and decoration called the linangkit gonob and the kuluwu that is common in the traditional costumes of the Lotud (s). The linangkit is a reference to the embroidery usually sewn using a technique called geometric motif or mer-upaka. The information in this article was procured through field work to a number of villages in Tuaran to document and categorize the aesthetics of the linangkit on the traditional costumes of the Lotud(s).

Keywords: Traditional costume, design, linangkit, aesthetics and indigenous practices.

\section{PENGENALAN}

Kebudayaan mempunyai pengertian yang berbeza-beza dan tidak terdapat titiktitik persamaan. Namun, kesemuanya mengakui bahawa prinsip kebudayaan itu adalah ciptaan manusia. Kewujudan dan perkembangan kebudayaan adalah signifikan dengan kehidupan batin atau pemikiran manusia. Menurut Sylvester Saraban (1989:9-11), asas kebudayaan Lotud serta kaum Kadazan yang lain adalah mempunyai persamaan dan pertalian berdasarkan kepada kepercayaan tentang kewujudan Maha Pencipta atau Minamangun yang dipanggil Kinohoringan.

Masyarakat Lotud di Tuaran mempunyai pelbagai budaya tradisi yang masih diamalkan secara turun- temurun. Antara budaya yang diamalkan adalah tarian tradisional, pakaian tradisional dan pelbagai adat ritual. Menurut Owen S. K. (1989:11-12), masyarakat Dusun Lotud mempunyai pakaian tradisional yang tersendiri seperti suku Kadazandusun yang lain. Justeru, masyarakat Lotud mempercayai bahawa pakaian tradisional mereka berasal daripada pakaian ketuhanan. Istilah pakaian bagi lelaki disebut Kinohoringan ${ }^{l}$, manakala pakaian perempuan disebut Umunsumund $u^{2}$. Mengikut cerita lisan, sungguhpun cara pakaian Kinohoringan dan Umunsumundu tidak pernah dilihat oleh masyarakat Lotud, cara berpakaian jelas diterangkan dalam rangkaian kata-kata rinait molukas ${ }^{3}$ oleh tantagas ${ }^{4}$. Rinait molukas dibacakan ketika mereka memberi puji-pujian tentang kelengkapan pakaian Kinohoringan dan Umunsumundu semasa berpindah ke rumah baharu yang disebut 'molukas'. Pada masa tersebut, pakaian lengkap mereka diterangkan melalui bait atau perkataan ritual secara satu persatu yang diceritakan dalam rinait molukas. Masyarakat telah mengadaptasi bait-bait jampi atau rinait itu dalam bentuk visual. Penciptaan pelbagai ornamen dan aplikasi visual yang digunakan telah melahirkan satu fesyen pakaian tradisional masyarakat Lotud. 


\section{KAEDAH KAJIAN}

Kajian ini dijalankan berdasarkan pendekatan etnografi yang bersifat kualitatif melalui penglibatan pengkaji secara terus di lapangan. Menurut Sabitha Marican (2005), kajian etnografi dianggap sebagai satu kajian yang paling asas dalam penyelidikan sosial. Kadangkala, ia juga didefinisikan sebagai penjelasan bertulis tentang sesuatu budaya, kepercayaan, tingkah laku yang berdasarkan kepada maklumat yang dikumpulkan dari kajian lapangan. Ia adalah kajian deskriptif ke atas budaya, subbudaya, institusi atau kumpulan sesebuah masyarakat.

Kajian seperti ini melibatkan kaedah pemerhatian, temu bual dan rekod data. Kajian khusus ini berfokuskan kepada pakaian tradisional Dusun Lotud dengan kompilasi dan susunan data-data serta maklumat yang bersumberkan tempat kajian, buku rujukan, media massa dan internet.

Penyelidikan etnografi umumnya menggariskan tiga pertimbangan. Pertama, membuat tinjauan literatur melalui kajian perpustakaan untuk mengenali subjek kajian demi memastikan siapa masyarakat kajian. Kedua, membuat himpunan dan koleksi subjek kajian melalui foto dan audio visual. Kajian ini melibatkan tinjauan dan analisis terhadap objek kajian di lapangan. Antara persoalan utama yang dibina adalah meliputi siapa pemilik pakaian tersebut dan mengapa ia mempunyai struktur reka bentuk dan ragam hias. Eksplorasi atau penerokaan selanjutnya dilaksanakan untuk mengenal pasti dari segi variasi, persamaan dan perbezaan elemen kajian. 


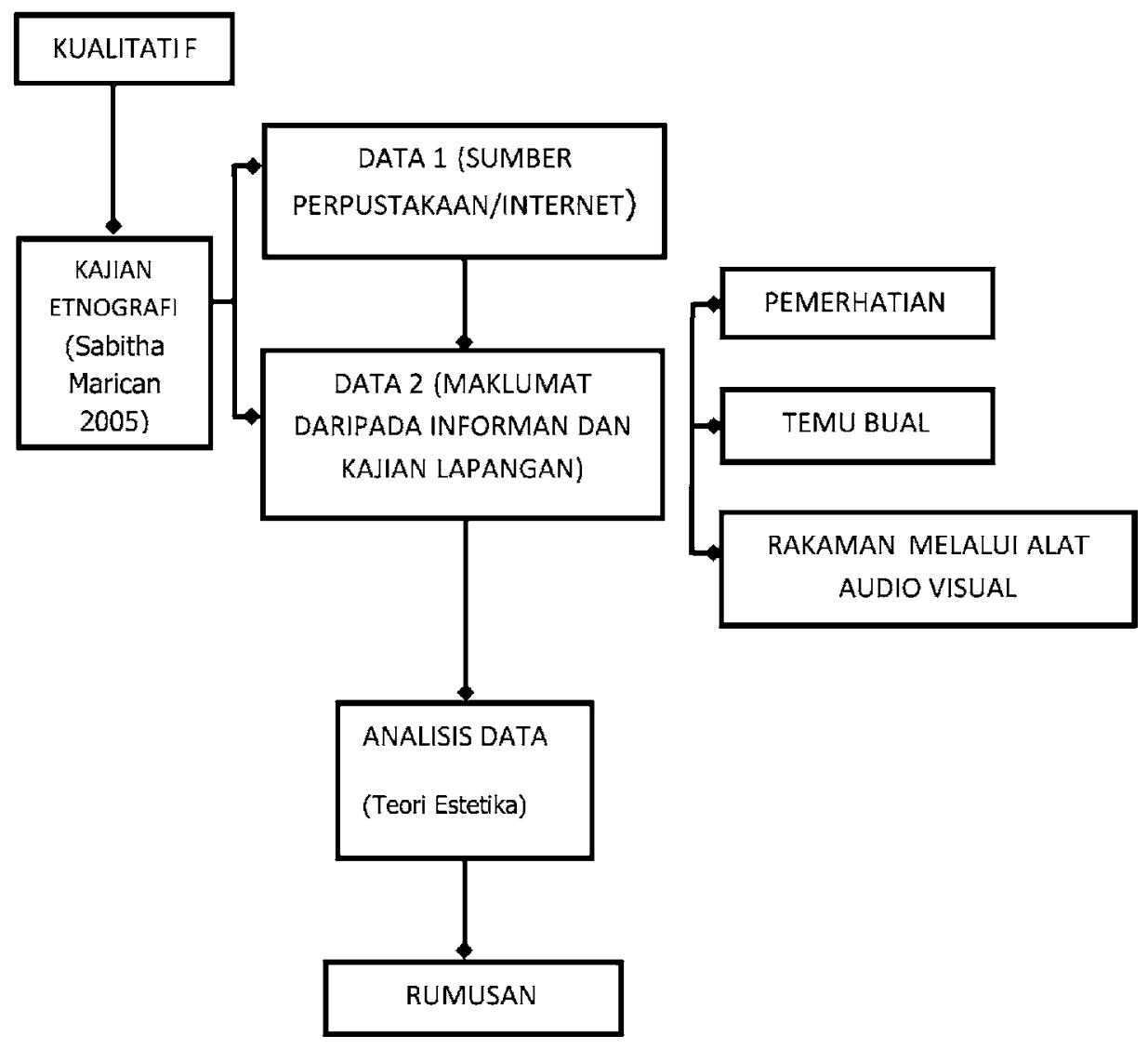

Rajah 1 Carta alir penyelidikan

Rajah 1 menunjukkan carta alir tentang strategi penyelidikan yang menjadi panduan kepada penyelidik dalam penyelidikan ini. Terdapat dua input utama dalam mendapatkan bahan kajian yang dipanggil data 1 dan data 2 . Data 1 merujuk kepada sumber sedia ada seperti buku dan internet. Data 2 pula merujuk kepada data baharu yang diperoleh di lapangan melalui 3 kaedah iaitu pemerhatian, temu bual dan rakaman audio visual. Penggabungan kedua-dua data ini membekalkan maklumat-maklumat yang diperlukan untuk dianalisis. Maklumat-maklumat yang dianalisis seterusnya dijangka dapat didokumentasikan sebagai bahan rujukan kepada pengkaji seterusnya. 


\section{LATAR BELAKANG MASYARAKAT LOTUD}

Kajian ini ditulis berdasarkan pemerhatian terhadap masyarakat Lotud di daerah Tuaran, Sabah. Masyarakat Dusun Lotud di negeri Sabah dipercayai berasal dari daerah Tuaran. Kaum ini menggunakan perkataan Suang Lotud sebagai mewakili identiti mereka. Dusun Lotud adalah salah satu kaum dalam subKadazandusun di Sabah. Sebahagian besar generasi muda orang Lotud pada masa kini telah menganuti agama Kristian dan agama Islam. Walau bagaimanapun, secara keseluruhannya kaum ini masih berpegang kuat kepada kepercayaan dan adatadat lama. Dari segi kebudayaan dan cara hidup, suku kaum Lotud mempunyai banyak persamaan berdasarkan amalan, kepercayaan dan adat istiadat kaum Kadazandusun. Asal usul rumpun Kadazandusun dipercayai daripada rumpun yang sama kerana mempunyai persamaan dari segi istilah dan bahasa.

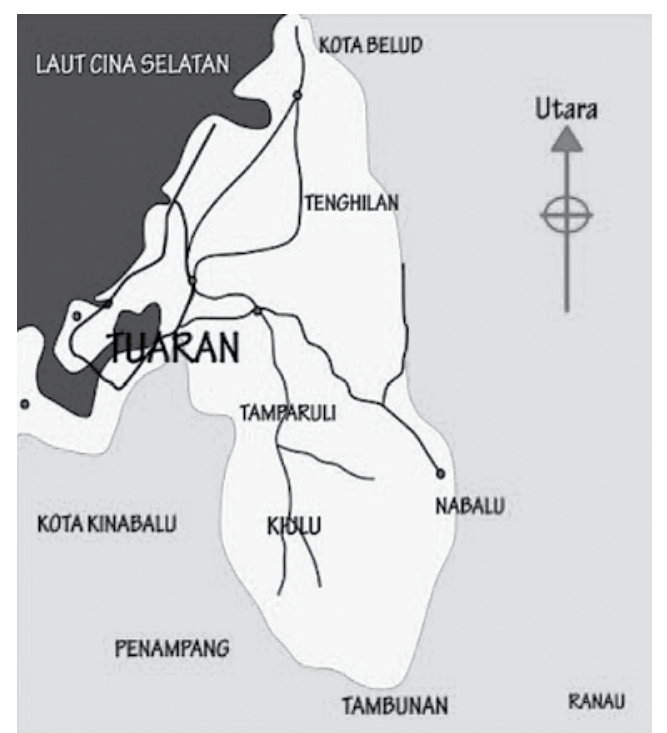

Sumber: Diubah suai daripada https://www.google.com.my/search?q=peta+tu-aran\&newwindow

Rajah 2 Petempatan masyarakat Lotud Tuaran

Rajah 2 menunjukkan petempatan masyarakat Lotud di Sabah. Kawasan yang berwarna putih adalah petempatan utama masyarakat ini. Kawasan tersebut terdiri daripada daerah Tuaran, Tenghilan, Tamparuli dan Kiulu. Kawasan ini terletak di antara jalan utama yang menghubungkan daerah Ranau dengan Kota Belud.

Asal usul Dusun Lotud adalah tidak jelas sehingga kini walaupun terdapat banyak teori daripada pengkaji barat dan tempatan telah dikemukakan. Pengkaji telah memetik teori daripada P.S. Shim (2007:17) dalam buku Inland People 
of Sabah before During and After Nunuk Ragang. Shim mengatakan bahawa Dusunics, Paitanics dan Ida'ans adalah orang pertama yang sampai ke Sabah sekitar tahun 1200 SM. Golongan Dusunics sampai ke Sabah melalui empat peringkat penghijraan sekitar tahun 1200 hingga 1700 SM. Golongan ini datang ke Sabah melalui Sungai Baram kerana melarikan diri dari penindasan orang Melanau. Kumpulan pertama telah sampai ke daerah Menumbuk dan dikenali sebagai Dusun Tatana ${ }^{5}$ sehingga pada masa kini. Kumpulan kedua pula dipercayai sampai di daerah Papar yang disebut Dusun Papar ${ }^{6}$ dan kumpulan ketiga kemudiannya sampai di daerah Tuaran yang menggelar diri mereka sebagai Suang Lotud. Kumpulan terakhir pula tiba di hulu Sungai $\mathrm{Liwogu}^{7}$ iaitu disebut Nunuk Ragang ${ }^{8}$. Penghijrahan ini telah menyebabkan golongan Kadazandusun tersebar luas dan membuat petempatan di seluruh pelosok negeri Sabah pada masa kini. Berikut merupakan ringkasan imigrasi tentang pergerakan etnik peribumi Sa- bah berdasarkan pendapat Shim, (2000).

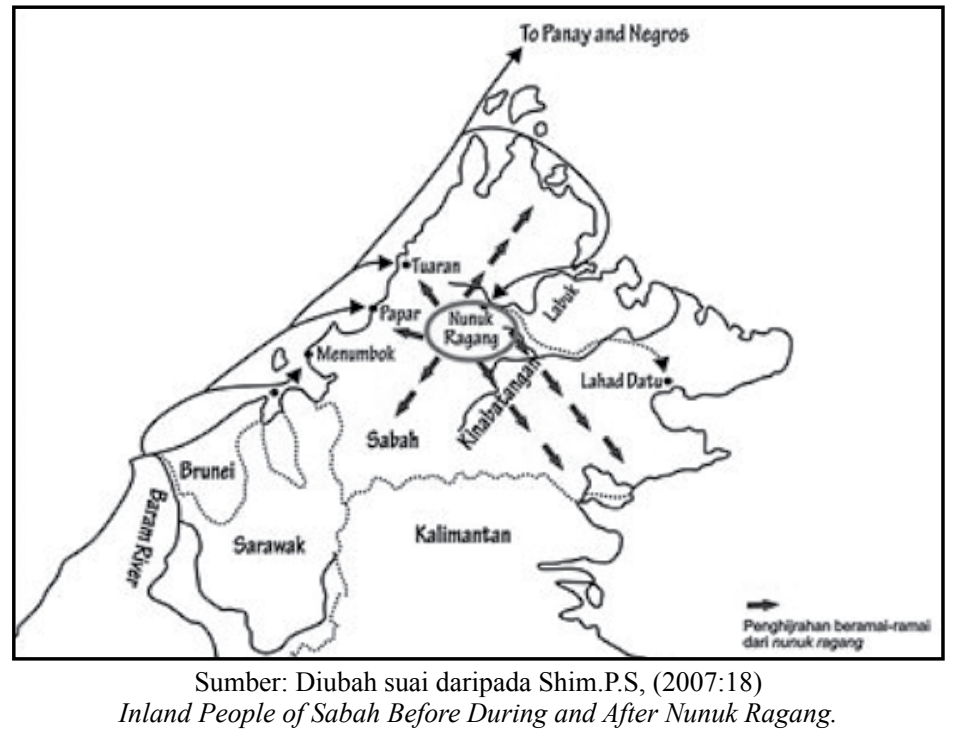

Rajah 3 Penghijrahan Dusunics di Sabah

\section{ADAT DAN BUDAYA PAKAIAN TRADISIONAL}

Pakaian tradisional masyarakat Lotud adalah hasil ciptaan daripada amalan adat oleh pengamalnya yang dipanggil momolian ${ }^{9}$ dan tantagas. Golongan ini bertanggungjawab untuk mengingatkan kaum mereka dalam hal ehwal adat Dusun Lotud, termasuk adat berpakaian. Menurut informan, ${ }^{10}$ adat berpakaian tradisional kaum wanita Lotud mempunyai beberapa ketentuan yang harus 
dipatuhi. Jika adat ini tidak diikuti, si pemakai akan dikenakan denda yang disebut sebagai sogit. Antara fokus adat dalam pemakaian masyarakat Lotud ialah adat pemakaian lilimbo, baju dan gonob.

Lilimbo merupakan sejenis tali pinggang yang dicipta khas sebagai hiasan pakaian yang diperbuat daripada rotan. Rotan dibentuk berlingkar-lingkar seperti spring. Lingkaran rotan halus ini diwarnai dengan warna yang berlainan iaitu merah, hitam serta coklat dan setiap warna mengandungi maksud atau makna tertentu. Perempuan yang belum berkahwin diwajibkan memakai lilimbo berwarna merah.

Bagi wanita yang sudah berumah tangga, mereka perlu memakai lilimbo yang digabungkan dengan warna merah dan hitam. Golongan tua pula harus memakai lilimbo daripada warna kuning rotan ataupun warna coklat. Kesalahan akan berlaku jika seorang wanita yang sudah berkahwin dan mempunyai anak memakai lilimbo berwarna merah. Kesalahan ini akan dikenakan denda atau sogit $^{11}$ ke atas anak-anaknya kerana perbuatan menyembunyikan status dirinya. Mengikut kepercayaan masyarakat Lotud, jika sogit tidak dikenakan dikhuatiri akan menyebabkan tulah atau berlaku perkara yang tidak baik kepada anakanaknya kelak.

\section{JENIS PAKAIAN TRADISIONAL}

Masyarakat Dusun Lotud mempunyai dua jenis pakaian tradisional iaitu pakaian untuk wanita dan pakaian untuk lelaki. Pakaian tradisional ini biasanya dipakai pada upacara-upacara penting dalam adat. Rajah 4 (i, ii, iii, iv, v, vi dan vii) merupakan tiga acara adat yang memerlukan pemakaian pakaian tradisional ketika berlangsungnya upacara tersebut. Pemakaian pakaian tradisional dikaitkan dengan upacara seperti yang berikut:

1. Pakaian Momolian dan Tantagas, upacara pemujaan semangat padi atau semangat jahat.

2. Pakaian penari sumayau untuk memohon berkat daripada kuasa supernatural atau untuk persembahan hiburan.

3. Pakaian semasa upacara perkahwinan. 


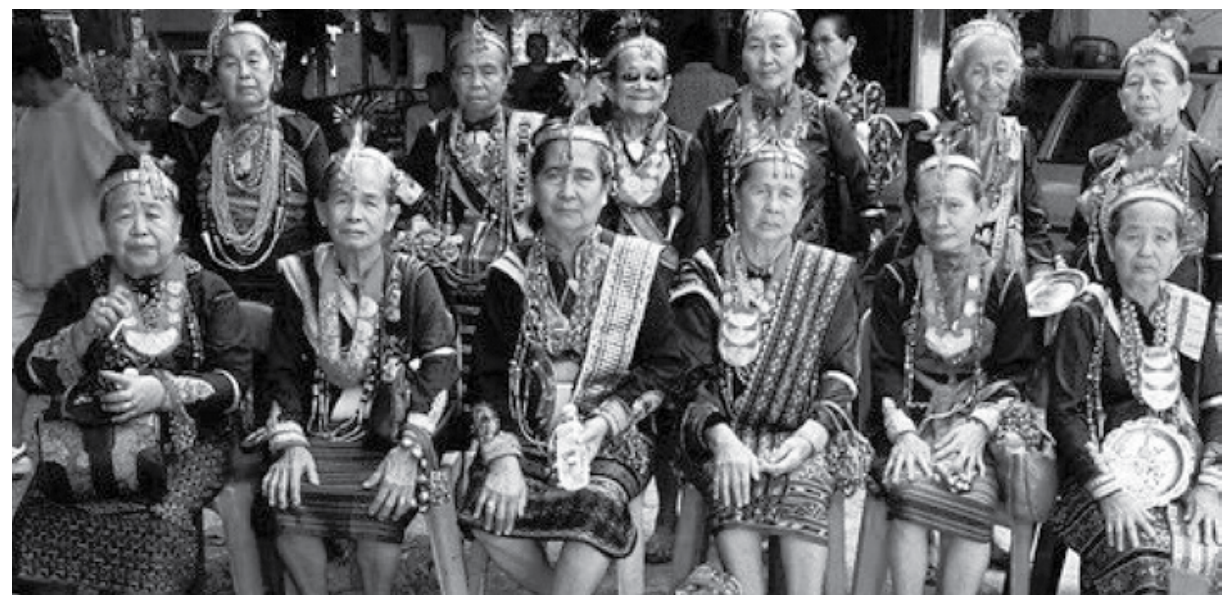

(i) Pakaian momolian dan tantagas dalam upacara pemujaan.
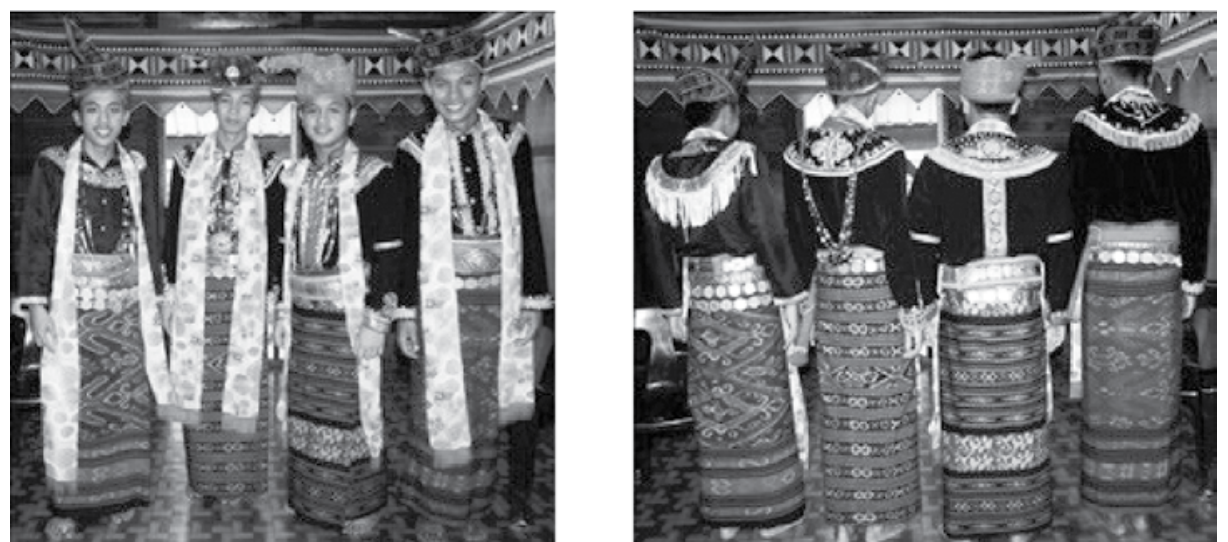

(ii) Pakaian penari sumayau lelaki (pandangan hadapan dan belakang).
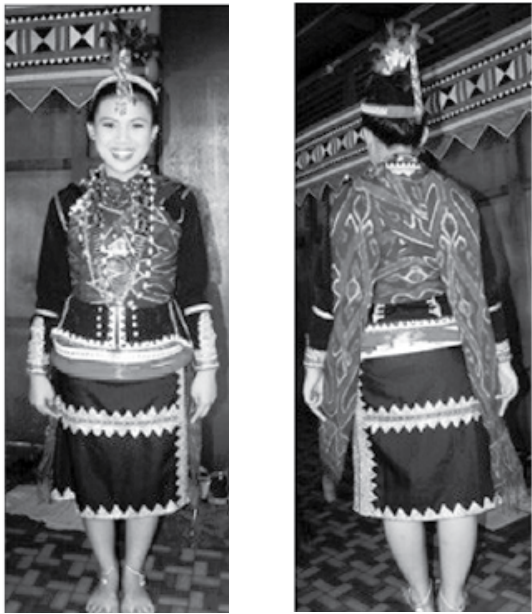

(iii) Pakaian penari sumayau (pandangan hadapan dan belakang). 


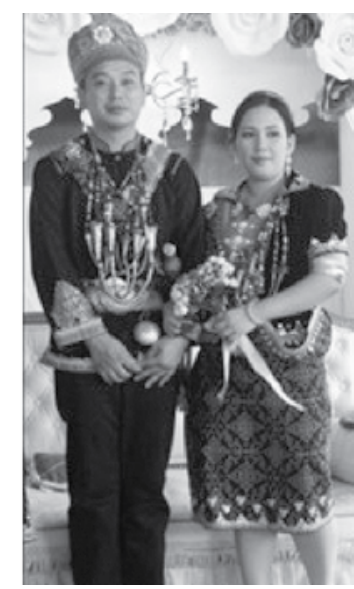

(v) Pakaian pengantin (sukob).

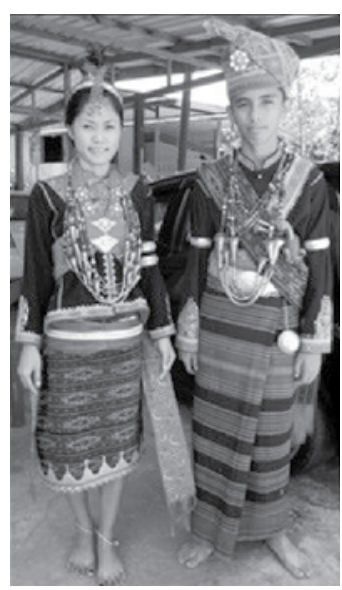

(iv) Pakaian pengantin (sukob kopio dan kain mugah).

Rajah 4 Pakaian tradisional masyarakat Lotud

Rajah 4 ( i hingga iv) menunjukkan pakaian tradisional masyarakat Lotud yang dibahagikan kepada tiga golongan, iaitu pakaian momolian dan tantagas bagi upacara pemujaan (ritual) [Rajah (i)], pakaian penari sumayau [Rajah (ii hingga v)] dan pakaian pengantin [Rajah (vi dan vii)]. Secara keseluruhannya, rekaan pakaian bagi ketiga-tiga upacara ini adalah hampir serupa, sama ada pakaian lelaki atau pakaian perempuan. Walau bagaimanapun, ciri-ciri dari segi hiasan baju atau sukob, aksesori serta tujuan pemakaiannya masih berbeza. Sebagai contoh, sukob momolian dan tantangas tidak dihiasi dengan motif manik seperti pakaian penari sumayau dan pakaian pengantin. Pakaian tantagas dan penari sumayau pula wajib memakai siwot dalam sesebuah upacara. Seterusnya, pengantin pula digalakkan memakai sigar.

\section{PAKAIAN TRADISIONAL KAUM LELAKI}

Reka bentuk pakaian tradisional bagi kaum lelaki Lotud adalah lebih sederhana berbanding dengan pakaian wanita. Pakaian lelaki terdiri daripada sepasang baju dan seluar berwarna hitam yang dihiasi dengan sulaman benang berwarna-warni. Pakaian lelaki mempunyai sarung tenun mugah. Kain mugah dihasilkan oleh kaum Bajau dan Rungus yang mempunyai kemahiran menenun yang tinggi. Mugah biasanya dipakai oleh penari sumayau yang dipasangkan dengan baju atau sukob. Pengantin lelaki dan pengamal adat pula lebih gemar memakai seluar atau binandus daripada mugah. Pakaian tradisional lelaki ini turut dilengkapi dengan beberapa perhiasan untuk menampakkan ciri estetika yang penuh dengan makna tersendiri mengikut kepercayaan masyarakat Lotud. 
Berikut merupakan pola lengkap pakaian dan perhiasan yang dipakai oleh kaum lelaki dalam adat berpakaian masyarakat Lotud.

a. Pakaian

1. Sukob - baju berlengan panjang dan berwarna hitam serta mempunyai hiasan corak di bahagian lengan dan dada.

2. Mugah - sejenis kain sarung yang ditenun.

3. Binandus - sejenis seluar panjang berwarna hitam tanpa hiasan.

4. Sundi-sejenis kain tenunan yang dipakai di kepala.

5. Haboi - kain putih yang berfungsi sebagai pengikat gonob (kain).

b. Perhiasan

1. Karoh - sejenis rantai yang panjang dan diperbuat daripada jaluran manik, kerang dan kayu.

2. Bubu tulan - tali pinggang yang diperbuat daripada perak.

3. Botungkat - tali pinggang yang diperbuat daripada duit syiling berasaskan perak.

4. Supuh - perak berbentuk sfera dan dipakai pada bubu tulan $^{12} \mathrm{di}$ sebelah kiri.

5. Tatarapan - keris yang diperbuat daripada perak.

6. Simpai - gelang tangan yang diperbuat daripada perak. 


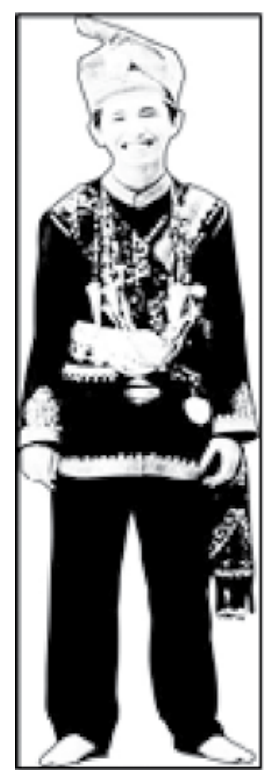

(i)

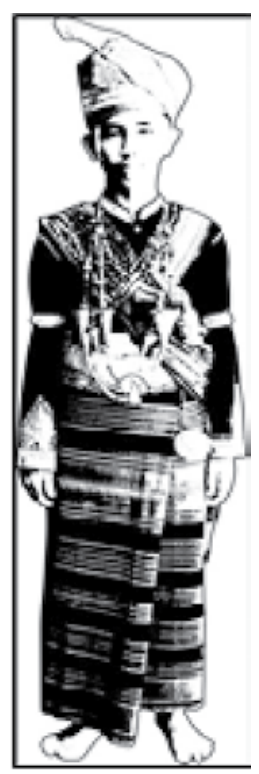

(ii)

Rajah 5 Pakaian tradisional kaum lelaki Lotud

Rajah 5 (i dan ii) menunjukkan pakaian tradisional kaum lelaki masyarakat Lotud. Rajah 5 (i) merupakan pakaian versi binandus, manakala Rajah 5 (ii) merupakan pakaian versi mugah. Pakaian tradisional lelaki Lotud berwarna hitam. Dominasi warna ini mendasari pakaian tersebut yang dihiasi dengan pelbagai motif dan corak sulaman benang berwarna terang seperti merah dan kuning. Pakaian ini juga dihiasi dengan pelbagai perhiasan yang diperbuat daripada bahan manik dan benang emas.

\section{PAKAIAN TRADISIONAL WANITA}

Rekaan pakaian tradisional masyarakat Lotud adalah sangat unik dan mempunyai reka bentuk dan ragam hias yang tersendiri. Pakaian wanita terdiri daripada sepasang baju dan gonob berwarna hitam yang dihiasi dengan sulaman benang berwarna-warni. Sukob merupakan panggilan bagi baju, manakala gonob adalah kain. Fesyen sukob kopio berlengan panjang atau variasi berlengan pendek yang dipanggil sukob dalam masyarakat Lotud. Fesyen kain gonob pula adalah pendek yang dipakai separas lutut. Kain gonob ini terdiri daripada dua jenis iaitu, gonob sinugitan dan gonob. Pada umumnya, rekaan kain adalah sama namun material yang digunakan dalam pembuatannya membezakan antara 
gonob sinugitan dan gonob. Gonob sinugitan diperbuat daripada kain yang ditenun, manakala gonob diperbuat daripada kain baldu atau kain berwarna hitam yang turut dihiasi dengan motif linangkit. ${ }^{13}$

Gonob sinugitan direka untuk dipasang kepada sukob kopio dan gonob pula direka khas sebagai pasangan kepada sukob. Walau bagaimanapun, dalam adat perkahwinan, pakaian sukob wajib dipadankan dengan gonob sinugitan dan kuluwu. Pakaian tradisional ini turut dilengkapi dengan perhiasan yang menampakkan ciri-ciri estetika yang penuh dengan nilai adat mengikut kepercayaan masyarakat Lotud.

Berikut merupakan pola lengkap pakaian dan perhiasan yang dipakai oleh kaum wanita dalam adat berpakaian masyarakat Lotud.

a. Pakaian

1. Sukob Kopio - baju blaus hitam berlengan panjang.

2. Sukob - baju blaus hitam yang berlengan pendek dan direka khas untuk dipasang dengan gonob linangkit.

3. Gonob sinugitan-merupakan sejenis sarung khas sebagai pasangan kepada sukob kopio.

4. Sandai - sejenis selendang panjang berukuran tiga meter. Kain ini dipakai dengan melilitnya pada badan atau diletakkan di atas bahu sebagai selendang.

5. Kuluwu - sejenis selendang yang dijahit secara bersambung pada hujung kain. Kain ini dipakai secara bersilang pada bahu sebelah kanan. Ia juga dipakai sebagai penutup kepala serta boleh diletakkan di atas tangan kanan sebagai hiasan. Kuluwu biasanya dipakai oleh pengantin yang dipadankan dengan sukob dan gonob.

6. Haboi - kain putih yang berfungsi sebagai pengikat gonob (kain). 


\section{b. Perhiasan}

1. Linangkit - merupakan nama panggilan kepada motif geometri yang menghiasi gonob. Gonob linangkit adalah panggilan kepada gonob berwarna hitam dan mempunyai rekaan yang sama dengan gonobsinugitan iaitu dipakai sepanjang paras lutut.

2. Siwot - adalah hiasan kepala, iaitu dicucuk pada rambut yang disanggul pada pengantin perempuan.

3. Sigar - adalah hiasan kepala berbentuk bulat yang dihiasi dengan jalur emas dan lilitan rotan berwarna merah.

4. Karoh - sejenis rantai atau kalung yang diperbuat daripada susunan manik, kaca, kerang dan potongan kayu yang berbentuk kon.

5. Mandapun - sejenis kalung yang diperbuat daripada kain merah dihiasi dengan kepingan emas.

6. Lilimbo - sejenis tali pinggang sebagai perhiasan yang diperbuat daripada rotan.

7. Botungkat - sejenis tali pinggang yang diperbuat daripada duit syiling berasaskan perak.

8. Simpai - sejenis gelang tangan yang diperbuat daripada perak. Simpai biasanya dipakai di atas siku tangan.

9. Lasung - sejenis gelang kaki yang diperbuat daripada perak. 


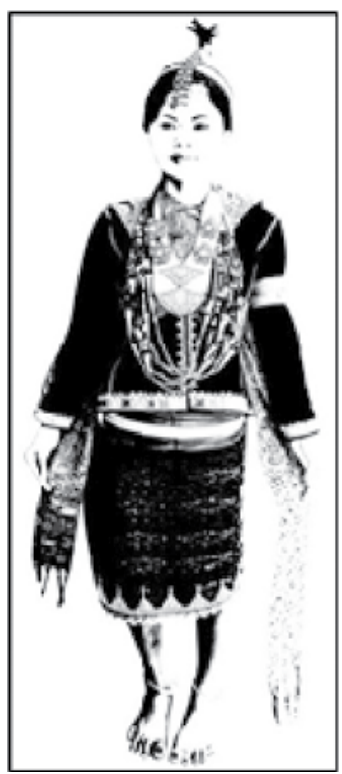

(i)

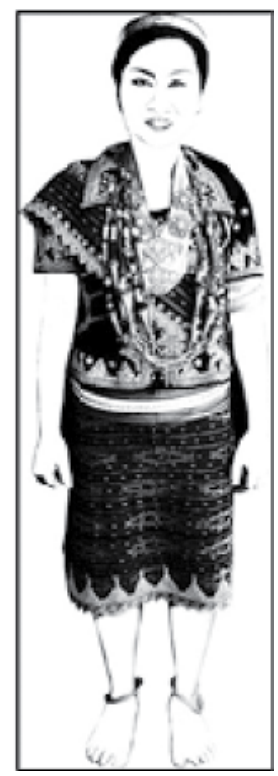

(ii)

Rajah 6 Pakaian tradisional kaum wanita Lotud

Rajah 6 (i dan ii) merupakan pakaian wanita Lotud. Rajah 6 (i) pula adalah pakaian versi sukob kopio dan Rajah (ii) merupakan pakaian versi sukob. Pakaian tradisional wanita Lotud adalah berwarna hitam yang dilengkapi dengan hiasan motif dan corak sulaman benang berwarna terang seperti merah dan kuning. Pakaian tradisional ini turut dihiasi dengan motif yang dipanggil $u k o b$ dan tinobugi dalam masyarakat Lotud. Motif ukob yang terdapat pada sukob kopio diperbuat daripada bahan manik dan benang emas.

Motif $u k o b$ merupakan motif yang wajib ada pada pakaian tradisional pengantin lelaki mahupun wanita. Motif ini bukan sahaja bertujuan untuk menjadi perhiasan pakaian tetapi ia terkandung dalam senarai adat masyarakat Lotud. Menurut informan, ${ }^{14}$ motif dan corak serta semua ragam hias yang terdapat pada pakaian tradisional Lotud terkandung dalam rinait tantangas. Oleh itu, mereka menghasilkan pakaian berdasarkan kepada arahan rinait yang diamalkan. 


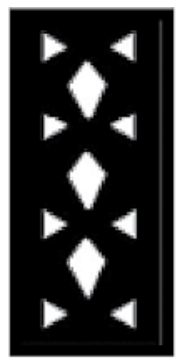

(i)

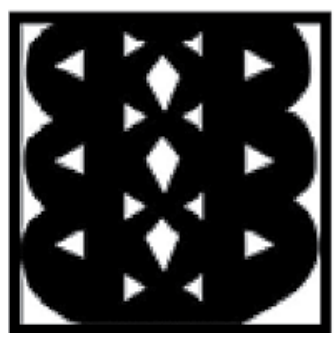

(iii)

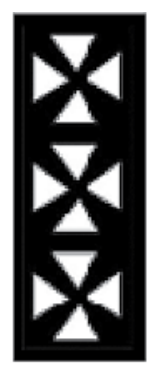

(ii)

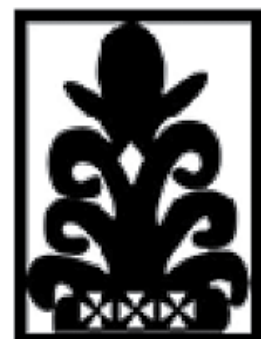

(iv)

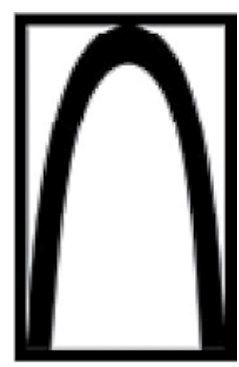

(iii)

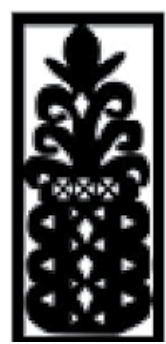

(v)

Rajah 7 Motif $u k o p$ pada sukob pengantin perempuan

\section{MOTIF SULAMAN LINANGKIT}

Terdapat motif yang dipanggil linangkit dalam pakaian masyarakat Lotud. Motif linangkit disulam pada gonob yang biasanya dipakai oleh penari sumayau. Motif linangkit (Rajah 8 (i hingga iv) mempunyai beberapa variasi bentuk yang diaplikasikan daripada bentuk geometri. Penggunaan warna pada motif linangkit telah menimbulkan keindahan dan keunikan pada motif ini. Linangkit dihasilkan dengan teknik sulaman benang untuk menghasilkan motif geometri. ${ }^{15}$

Dalam masyarakat Lotud, linangkit lazimnya digunakan sebagai penghias pada bahagian tepi gonob dan bahagian kepala kuluwu. Menurut informan, ${ }^{16}$ linangkit adalah satu hasil kerja tangan asli yang diwarisi daripada nenek moyang sejak turun-temurun. Mengikut cerita, penyulam linangkit juga terdapat dalam kalangan kaum Iranun di Kota Belud, kaum Rungus di Kudat dan kaum Lotud di Tuaran. Lazimnya, motif linangkit dihasilkan dengan berlatarbelakangkan kain berwarna hitam. Linangkit dihasilkan dengan teknik sulaman benang yang membentuk pola secara membujur dari atas ke bawah pada sesebuah rekaan corak pakaian. 


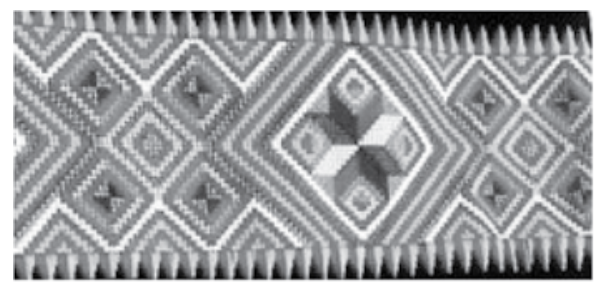

(i)

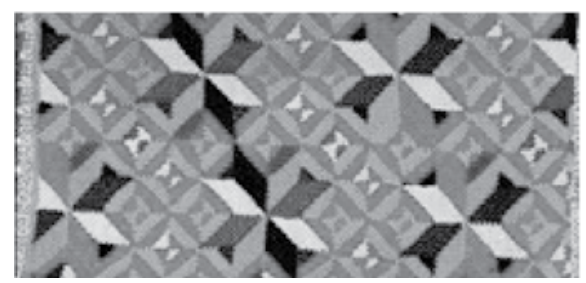

(iii)

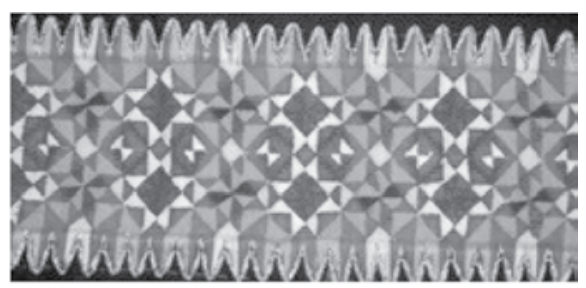

(ii)

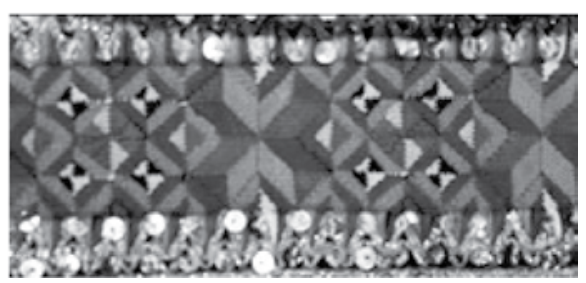

(iv)

Rajah 8 Imej linangkit

Masyarakat zaman dahulu menggunakan benang sebagai asas pembuatan linangkit yang dihasilkan daripada tumbuhan semula jadi seperti bahan sabut atau serat daun nanas. Sebagai contoh, sabut daun nanas ini dipintal menjadi benang serta diwarnakan dengan kunyit bagi menghasilkan warna kuning dan bahan tursih $^{17}$ untuk menghasilkan warna hitam. Warna merah pula dihasilkan dengan menggunakan warna alam seperti kulit bakau atau kayu cendana. Walau bagaimanapun, penggunaan bahan-bahan tersebut semakin pupus setelah bahanbahan moden yang lebih mudah diperoleh di pasaran.

Pada masa kini, penggunaan motif linangkit telah mengalami perubahan kerana penambahan perhiasan yang didominasikan dengan bahan manik dan labuci sebagai hiasan pakaian tradisional, terutamanya pada gonob ${ }^{18}$ dan kuluwu. $^{19}$ Linangkit dijahit secara menegak dan melintang di bahagian tengah gonob dan kuluwu [Rajah 9 (i dan ii)]. Terdapat beberapa variasi motif linangkit yang telah dihasilkan oleh masyarakat Lotud yang menampilkan nilai estetika tersendiri. Penggunaan warna yang bersesuaian juga menjadikan motif linangkit ini menjadi unsur tarikan pada hiasan gonob linangkit dan kuluwu. 


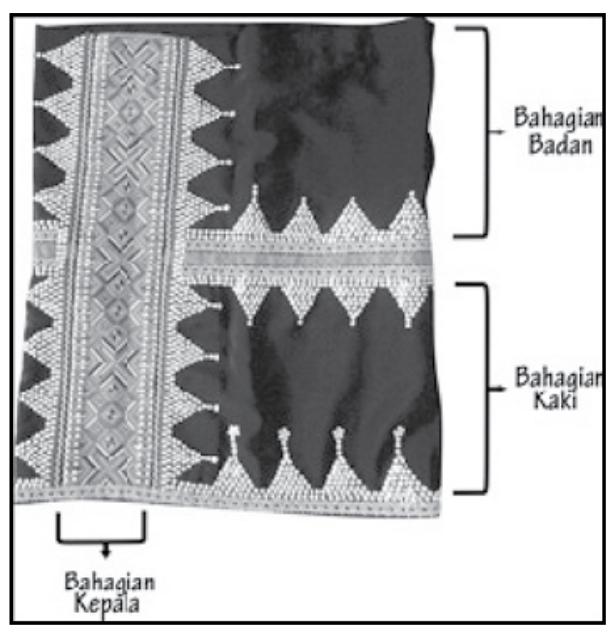

(i) Gonob

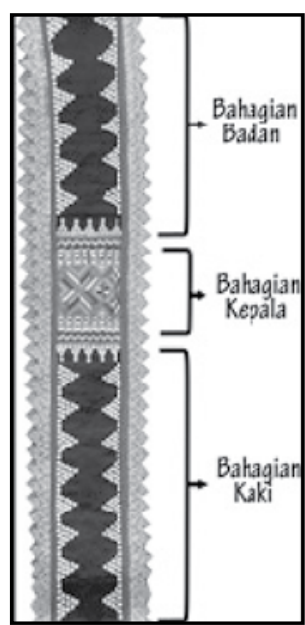

(ii) Kuluwu

Rajah 9 Motif linangkit pada gonob dan kuluwu

Rajah 9 (i dan ii) menunjukkan imej sebenar gonob dan kuluwu. Dalam rajah ini, imej linangkit dijahit secara menegak pada bahagian tepi gonob dan bahagian kepala kuluwu. Lazimnya, saiz linangkit yang dijahit pada gonob adalah berukuran $25 \mathrm{~cm}$ lebar, manakala panjangnya adalah bergantung kepada saiz panjang gonob itu. Bagi kuluwu pula, linangkit dijahit berukuran $25 \mathrm{~cm}$ panjang dan lebarnya mengikut saiz kuluwu. Pada kebiasaannya, lebar kuluwu tidak melebihi $25 \mathrm{~cm}$.

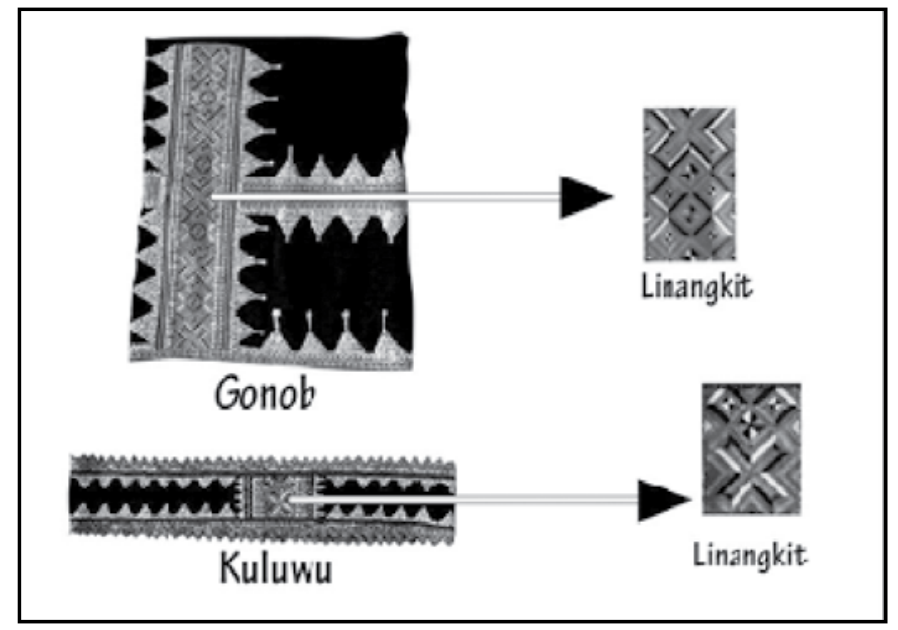

Rajah 10 Imej linangkit pada gonob linangkit dan kuluwu 
Corak linangkit (Rajah 10) adalah bercirikan rupa bentuk geometri yang didominasi dengan bentuk segi tiga dan segi empat. Penggunaan warna-warna terang seperti warna merah, kuning, hitam, hijau dan putih dicipta untuk mengisi setiap bentuk geometri yang dibentuk sehingga menjadi corak yang pelbagai. Corak-corak yang dibentuk disulam secara berulang-ulang bersaiz kecil dan besar. Ia ditenun secara berulang membentuk pola-pola corak yang menimbulkan nilai estetika.

Terdapat beberapa istilah pada corak linangkit yang biasa disulam oleh masyarakat Lotud, piniutu (bercantum), linodi (bersambung), nabur-abur (bertabur atau berselerak), olinsong sadur (biji tembikai), kinuyung-kuyung (berombak), subor (hiasan tambahan) dan piniating (berulang). Rajah 11 (i hingga ix) adalah motif, corak dan bentuk linangkit yang divariasikan kepada beberapa imej.

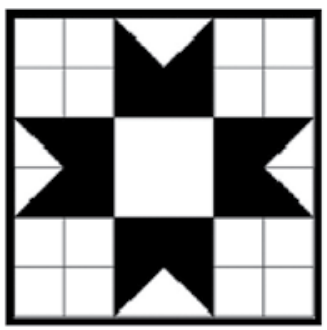

(i) Linodi

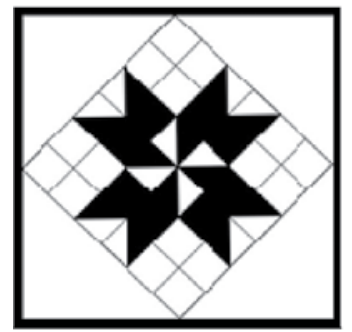

(iv) Pinitu

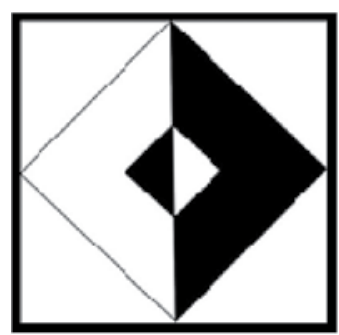

(vii) Olinsung sadur

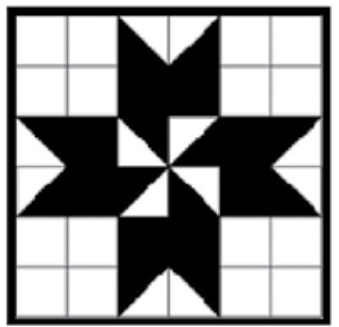

(ii) Piniutu

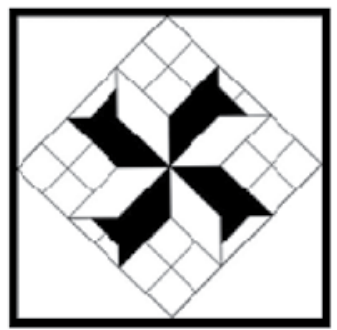

(v) Nabur-abur

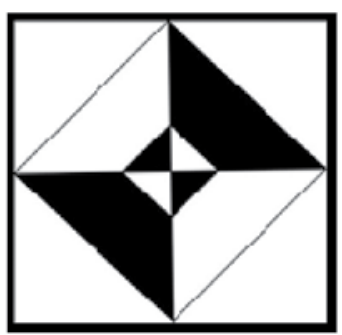

(viii) Subor

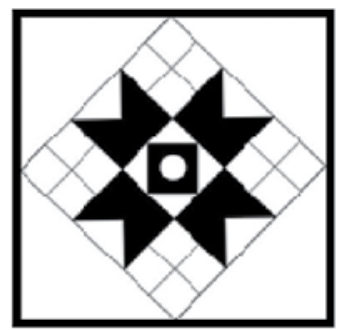

(iii) Linodi

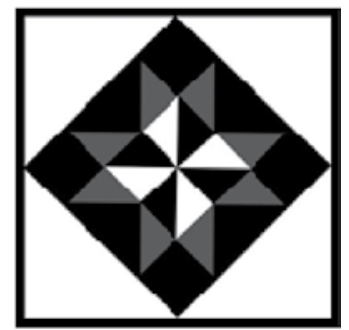

(vi) Nabur-abur

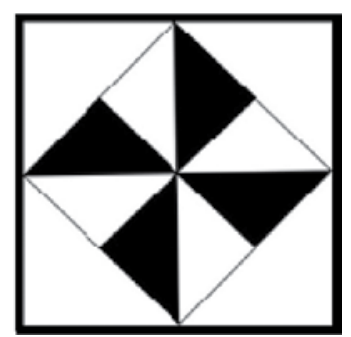

(x) Subor

Rajah 11 Motif asas linangkit 
Rajah 11 (i hingga x) merupakan pembentukan beberapa variasi motif linangkit. Gabungan daripada corak seperti dalam [Rajah 11 (i hingga $\mathrm{x}$ )] telah menghasilkan beberapa variasi linangkit oleh penyulam Lotud. Variasi motif linangkit terbentuk hasil daripada pengulangan corak yang dapat diklasifikasikan seperti imej translasi, cerminan, putaran, imej pengulangan komposisi dan penggunaan imej positif-negatif. Dominasi motif linangkit [Rajah 11 (i hingga ix)] dan [Rajah 12 (i hingga ix)] diasaskan daripada bentuk segi empat dan segi tiga yang disulam mengikut garis lurus dan berorientasikan unsur geometri.

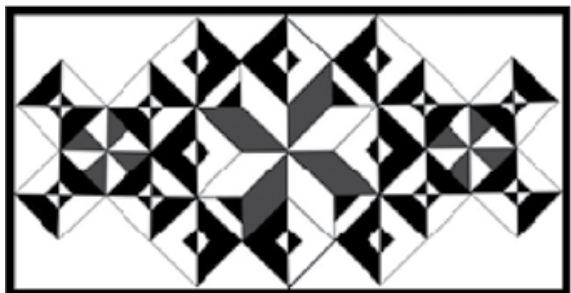

(i) Piniutu

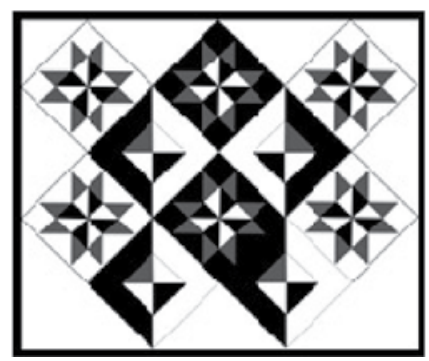

(iii) Nabur-abur

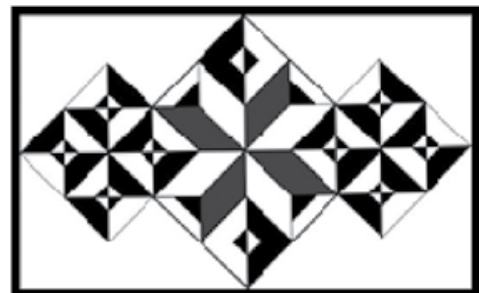

(ii) Piniating

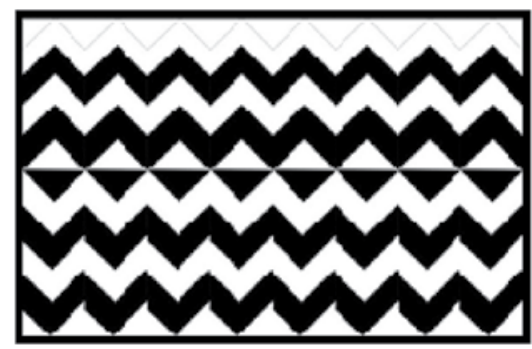

(iv) Kinuyung-kuyung

Rajah 12 Variasi corak linangkit ${ }^{20}$

Rajah 12 (i hingga iv) merupakan variasi corak asas linangkit yang disusun secara berulang-ulang bertujuan menghasilkan pola corak yang menarik. Corak asas linangkit ditransformasi dengan pengulangan corak dan penggabungan rupa pada corak. Gabungan corak asas ini telah menghasilkan variasi linangkit untuk menghiasi pakaian masyarakat Lotud. 


\section{NILAI PAKAIAN DAN LINANGKIT DALAM MASYARAKAT LOTUD}

Pakaian menunjukkan ketamadunan manusia yang berfungsi sebagai penutup tubuh badan. Selain daripada itu, budaya berpakaian merujuk kepada persepsi untuk cantik, berfesyen dan corak yang estetik. Nilai pakaian tradisional pada upacara ritual berfungsi untuk memanggil semangat pemujaan supernatural yang dianggap rapat dengan hubungan manusia dengan Tuhan atau dewa mereka. Pakaian tradisional merupakan satu pakaian yang tercipta dari gambaran pakaian Tuhan mereka, iaitu Kinorohingan bagi pakaian lelaki dan Umunsumundu bagi pakaian wanita. Masyarakat Lotud tidak memakai pakaian ini tanpa tujuan kerana pakaian tersebut merupakan pakaian yang mempunyai unsur ketuhanan dan diangap suci. ${ }^{21}$

Nilai pakaian tradisional dalam adat perkahwinan merujuk kepada keindahan budaya masyarakat melalui adat perkahwinan tradisi. Acara perkahwinan dalam masyarakat Lotud merupakan acara yang besar dan wajib dijalankan. Perkahwinan melibatkan dua keluarga besar daripada pengantin lelaki dan wanita. Semasa upacara perkahwinan, keluarga pengantin mengadakan upacara besar-besaran seperti jamuan makan dan persandingan pengantin. Semasa persandingan, keluarga pengantin berusaha menampilkan pakaian pengantin untuk kelihatan cantik dan berseri. Maka, pakaian tradisional merupakan aspek yang penting dalam soal kecantikan dan keceriaan pengantin yang menjadi identiti orang Lotud. Oleh itu, pakaian tradisional dalam perkahwinan adalah satu aspek yang dapat memberi kesan terhadap jati diri untuk melestarikan warisan budaya.

Dalam aspek tarian pula, nilai pakaian tradisi merujuk kepada semangat pemujaan supernatural semasa upacara ritual. Pakaian tradisional dipakai semasa menarikan tarian sumayau untuk memuja dan berhubung dengan kuasa supernatural. Pakaian dalam upacara ini menjelaskan signifikan pakaian dengan adat dan budaya. Walau bagaimanapun, nilai pakaian dalam tarian yang bukan bertujuan untuk ritual tetap menjadi lambang identiti orang Lotud. Tarian sumayau pula bukan sahaja ditarikan semasa ritual tetapi juga dalam acara perkahwinan dan persembahan. Pakaian penari pada masa kini adalah merujuk kepada pakaian lelaki dan wanita masyarakat Lotud semenjak dahulu.

Pakaian tradisional masyarakat Lotud juga melambangkan status mereka terutamanya kaum wanita, perhiasan pinggang yang disebut lilimbo. Lilimbo berwarna merah melambangkan status bujang, warna hitam melambangkan status berkahwin dan warna coklat atau warna rotan melambangkan status wanita yang sudah lanjut usia. 
Linangkit yang dihasilkan oleh masyarakat Lotud dapat dikaitkan dengan amalan adat dan budaya yang diturunkan oleh nenek moyang mereka. Para penyulam yang diajar secara lisan oleh penenun terdahulu telah meneruskan amalan ini demi memelihara warisan budaya. Motif dan corak linangkit kaum Lotud telah diteruskan oleh generasi muda dengan menampilkan idea dan ilham yang berkembang kepada beberapa variasi baharu.

Motif linangkit mempunyai keunikan dan keindahan yang tersendiri yang diperoleh menerusi cetusan idea daripada alam semula jadi. Para penenun mendapatkan motif linangkit daripada sumber alam dan mengolahnya semula sehingga menghasilkan motif linangkit. Motif linangkit adalah seperti motif olinsong sadur (biji tembikai), piniutu (bercantum), nabur-abur (bertabur atau berselerak), subor (hiasan tambahan) dan piniating (berulang). Idea tentang alam semula jadi jelas menggambarkan masyarakat Lotud yang peka terhadap sumber alam.

Aktiviti sulaman merupakan aktiviti yang sangat sukar dan memerlukan kerja tangan yang teliti. Para penyulam linangkit mempunyai nilai kerajinan yang tinggi untuk menghasilkan sulaman. Penyulam linangkit lazimnya adalah daripada golongan wanita. Bagaimanapun, aktiviti menyulam merupakan aktiviti sampingan mereka di rumah, selain daripada aktiviti seharian di ladang. Menyulam linangkitsecara tidak langsung dapat memberikan pendapatan sampingan kepada kaum wanita. Menurut informan, harga pakaian tradisional Lotud adalah sangat mahal kerana nilai penciptaan motif linangkit yang bermutu. Lazimnya, harga linangkit yang bersaiz $25 \mathrm{~cm}$ panjang dan $38 \mathrm{~cm}$ lebar adalah lebih dari RM 300. Harga yang tinggi ini boleh dijadikan sumber pendapatan lumayan dalam kalangan penenun Lotud.

\section{PERANAN LINANGKIT DALAM MASYARAKAT LOTUD}

Linangkit merupakan salah satu motif bersulam yang mendominasi pakaian tradisional Dusun Lotud. Bagi menghimpunkan warisan kebudayaan Lotud terutamanya dalam budaya pakaian, masyarakat Lotud telah menubuhkan persatuan. Persatuan ini menjalankan aktiviti kebudayaan mereka di tempat yang dipanggil rumah linangkit atau Linangkit Cultural Village. Pusat budaya ini boleh ditemui di Kampung Selupoh, Tuaran. Selain pertubuhan ini, terdapat beberapa persatuan kebudayaan lain yang telah ditubuhan seperti Persatuan Warisan Budaya Lotud di Kampung Tagas, Tuaran. 
Penubuhan beberapa persatuan ini membuktikan bahawa linangkit mempunyai peranan yang besar dalam masyarakat Lotud. Linangkit secara keseluruhannya mencerminkan peranannya dalam pemeliharaan kebudayaan Lotud agar tidak hilang ditelan zaman. Masyarakat Lotud juga memanfaatkan persatuan kebudayaan ini supaya amalan adat mereka sentiasa terjaga agar tidak dilupakan oleh generasi muda. Selain daripada itu, kelas menjahit dan menenun terus dimajukan di samping menghasilkan aksesori pakaian tradisional Lotud di daerah Tuaran.

\section{KESIMPULAN}

Pakaian tradisi adalah satu warisan pusaka dan lambang kebanggaan masyarakatnya. Pakaian tradisi Lotud yang lengkap tidak semudah yang disangka dari segi penyediaan, kewangan dan mendapatkan bahan-bahan kelengkapannya. Sepasang pakaian tradisi Lotud yang lengkap sekurang-kurangnya berharga antara RM2 ribu hingga RM3 ribu. Pakaian tradisi Lotud sangat tinggi nilainya kerana sukar dihasilkan. Motif geometri yang terdapat pada linangkit menjelaskan pemikiran penenun Lotud. Motif dan corak adalah hasil daripada ilham penenun terhadap alam semula jadi dan persekitaran meraka.

Golongan yang berkemampuan dan berkemahiran untuk menjahit sahaja yang mampu memilikinya. Walau bagaimanapun, kebanyakan pakaian tradisi ini telah diubah suai terutamanya dari segi reka bentuk dan ragam hiasnya. Namun, pakaian ini masih wajib dipakai pada waktu perayaan seperti perkahwinan dan Pesta Kaamatan.

\section{RUJUKAN}

A.Samad Hadi. (1983). Pendekatan kajian etnografi Sabah. Bangi: Universiti Kebangsaan Malaysia.

Arena Wati. (1978). Dusun. Kota Kinabalu: Penerbitan Yayasan Sabah.

Evans, I.H.N. (1923). Religion, folkfore in North Borneo and the Malay Peninsula. London: The Cambridge University Press.

G.C Woolley. (1937). Tuaran Adat (Some custome of the Dusun of Tuaran). Kota Kinabalu: North Borneo Civil Service.

G.C Woolley \& Danny Wong Tze Ken. (2006). Tuaran Adat. Kota Kinabalu: Natural History Publication (Borneo) Sdn. Bhd.

Irene Benggon-Charutuks. (1992). Cultures, customs and traditionals of Sabah. Kota Kinabalu: Sabah Tourism Promotion Corporation. 
Japuin Madisah. (1986). Tatacara adat istiadat dan kebudayaan Kadazan. Kota Kinabalu: SIKUK Publication.

Muzium Sabah Kota Kinabalu. (1992). Warisan Sabah. Kota Kinabalu.

Owen S. K. \& Daniel S. S. (1989). Pesta Kaamatan. Kota Kinabalu: Arkib Negeri Sabah.

Raymond Boin Tumbong. (1990). Keluarga Dusun. Kota Kinabalu: SQS Printing.

Rita Lasimbang. (1997). An introducation to the traditional costum of Sabah. Kota Kinabalu Sabah: Natural History Publication.

Sabitha Marican. (2005). Kaedah penyelidikan sains sosial . Petaling Jaya: Prentice Hall.

Shim P.S. (2007). Inland people of Sabah before during and after Nunuk Ragang. Kota Kinabalu: Borneo Culture Heritage Publisher.

Sylvester Saraban Daniel Buku. (1989). Pesta Kaamatan. Kota Kinabalu: Arkib Negeri Sabah.

Williams Thomas Rhys. (1965). The Dusun, a North Borneo Society. New York: Holt, Rinehart and Winston. 
